\title{
Conflictual and cooperative childcare politics in Canada
}

\author{
Rachel Langford $^{1 *}$, Susan Prentice ${ }^{2}$, Brooke Richardson $^{1}$ and Patrizia Albanese
}

\author{
*Correspondence: \\ rlangfor@ryerson.ca \\ ${ }^{1}$ School of Early \\ Childhood Studies, Faculty \\ of Community Services, \\ Ryerson University, 350 \\ Victoria Street, Toronto, ON \\ M5B 2K3, Canada \\ Full list of author information \\ is available at the end of the \\ article
}

\begin{abstract}
In 2005, after many years of inaction, the Canadian government seemed poised to make real changes to national childcare policy - a marker of social movement success for the grassroots Childcare Advocacy Association of Canada (CCAAC). In this paper, we analyse childcare policy developments in Canada between 2003 and 2005, drawing on qualitative interviews conducted with CCAAC staff and members, allies from other national childcare organizations, and former elected government officials and policy makers. Given its role as a grassroots social movement organization and not a professional association (which can be more closely aligned with governments), we hypothesized that the CCAAC would take a conflictual approach to the federal government's policy initiative. Our close analysis of interviews with CCAAC staff, their allies and elected government officials and civil servants instead reveals conflictual and cooperative relations (Giugni and Passy, In: From contention to democracy. Lanham, MD, Rowman \& Littlefield. 1998) during this important period. Our discussion explores some possible conditions in the sociopolitical environment and the internal structure of CCAAC that account for this conflictual-cooperation SMO-government relationship from 2003 to 2005.
\end{abstract}

Keywords: Childcare policy, Canadian childcare advocacy, Contentious politics, Conflictual cooperation, Government, Policy development

\section{Background}

Since World War II, generations of parents, women's and anti-poverty groups, labour and other allies, have fought for a national, high-quality, affordable and accessible childcare system in Canada (Friendly and Prentice 2009). Over the decades, each of these groups has drawn on a range of rationales, variously positioning the need for out-ofhome childcare as: a gender equity measure; targeted assistance for immigrant and working class/single mothers; a poverty reduction strategy; a strategy for balancing work and families; a social investment for creating future effective workers; a tool for child development during critical years; and an economic stimulus strategy (Prentice 2009). At stake in each rationale are concrete policy outcomes which include whether childcare should be a universal or targeted programme (or both); a market or publicly funded system; and whether fees should be cost shared (with families) or be fully covered by public dollars. Over these years, the Child Care Advocacy Association of Canada (CCAAC) and other pro-childcare social movement organizations have adopted different advocacy

(C) 2016 Langford et al. This article is distributed under the terms of the Creative Commons Attribution 4.0 International License (http://creativecommons.org/licenses/by/4.0/), which permits unrestricted use, distribution, and reproduction in any medium, provided you give appropriate credit to the original author(s) and the source, provide a link to the Creative Commons license, and indicate if changes were made. 
tactics, some more 'radical' and politicized and others more conciliatory, depending on the political climate and mitigating social and organizational circumstances. In 2005, after decades of childcare advocacy and government inaction, national childcare advocates finally expected their work to achieve policy success. Through a detailed analysis of qualitative interviews conducted with CCAAC staff, some of their allies, and former elected government officials and civil servants, this paper identifies and critically assesses-as conflictual, cooperation or conflictual-cooperation-the strategies that childcare advocates adopted in working with and/or against the Paul Martin Liberal government leading up to this expected policy success. We further explore conditions in the sociopolitical environment and/or in CCAAC's organizational structures that opened up the possibilities for cooperation between CCAAC and the Liberal government from 2003 to 2005.

Childcare resurfaced as a key national policy issue in 2003, when the Jean Chrétien Liberal government passed the multilateral framework agreements on early learning and childcare (MFA). The MFA committed $\$ 1.05$ billion for the creation of a childcare programme across the provinces and territories (Friendly and Prentice 2009). This policy announcement appears to have been motivated by the Liberal's turn towards social investment, a move from their earlier rigid neo-liberalism. Dobrowolsky (2009, p. 10) explains the underlying motivation behind social investment spending: "investments in education, innovation, healthcare, and children (particularly child at risk) would 'pay off' later by producing skilled, productive workers and preventing a host of expensive social ills".

Likely related to the fact that Chretien's Liberal government was operating at a surplus and hence was relatively generous, the MFA was well received by all provinces and territories. The MFA set the groundwork for the Paul Martin Liberal government's early learning and childcare (ELCC) Foundations programme rooted in the "QUAD" principles: quality, universal, accessible and developmentally appropriate early learning and childcare services across the country (Friendly and Prentice 2009). By late 2005, the federal Liberal government had signed bilateral agreements-in-principle with each Canadian province/territory (with the exception of Quebec, which began developing its own generous, $\$ 5$-day childcare programme in 1997) to launch a national childcare system based on the Foundations programme (Albanese 2009). While this paper focuses primarily on advocate-federal government relations between 2003 and 2005, it is important to note that the day after the newly elected Conservative government took office in 2006, the bilateral agreements were cancelled. Immediately after his swearing-in ceremony, Conservative Prime Minister Stephen Harper announced that the incumbent ELCC Foundations programme would be replaced with a universal child care benefit (UCCB) - \$100 (monthly and taxable) given to mothers with children under the age of six. ${ }^{1}$ This policy shift was described by the Manitoba Family Services Minister at the time as the "greatest U-turn in social policy". (Bailey 2008). Childcare advocates were quick to point out that shifting to a childcare benefit would not increase families' access

${ }^{1}$ In October 2014, the UCCB (likely in preparation for the 2015 federal election) was increased to $\$ 160$ (taxable) payable to each child under the age of six. In addition, $\$ 60$ (taxable) per month, again payable to the parent by default, was introduced for children between the ages of 7 and 18 . 
to high-quality, affordable childcare programmes (CCAAC 2005). They were proven right. By 2008, UNICEF reported that Canada ranked last among twenty-five comparator countries by "failing to attain nine of UNICEF's ten benchmark indicators of quality and access in ECEC provision" (Friendly and Prentice 2009, p. 3). In addition, national childcare advocacy organizations were stripped of government funding, making mobilization extremely difficult (Langford et al. 2013). But before this occurred, there were interesting developments and relations between the Liberal government and the CCAAC, Canada's only national grassroots childcare organization.

\section{The childcare movement landscape in Canada}

In Canada, a network of national and provincial childcare advocacy organizations and allies has expanded and narrowed as governments have affirmed and wavered in their commitments to childcare policy. The network has included at least four types of social movement organizations (SMOs): grassroots multi-issue advocacy organizations (including representation from women's groups, student federations, anti-poverty); professional ECEC workforce sector associations; childcare research-based organizations (including those doing childcare policy research and child development and population health research); and some trade unions that focus on the childcare needs of their members. All four types of SMOs are considered part of the Canadian childcare advocacy movement, but each can be distinguished by its organizational structure, membership base, resources available and tactics used to pursue the common goal of a national childcare strategy (Snow and Soule 2010).

For this paper, we selected the Childcare Advocacy Association of Canada (CCAAC) as a case study of state-SMO relations, given its unique position as a grassroots organization that worked with the Liberal government between 2003 and 2005 to develop a national childcare policy. The CCAAC, established in 1982 as a national multi-sector grassroots organization, is distinguished from the Canadian Child Care Federation (CCCF) in several ways. First, the CCAAC emerged as a women's rights advocacy organization, unlike the more professional CCCF, whose orientation is to provide resources for the ECEC workforce. CCCF members include individuals, representatives from provincial and territorial professional associations and service providers from the ECEC sector. Second, the CCCF has always had paid staff, though they experienced defunding and downsizing following the election of the Conservative government in 2006 (Langford et al. 2013). Finally, as a result of its governance structure, membership base and the increasing constraints of charitable status, the CCCF has adopted an 'insider' (Briskin and Eliasson 1993; Tyyska 1998) approach to working with government, keeping its public position neutral and strictly non-partisan. In contrast, members of the CCAAC (which have not registered charity status) is governed by a board of directors with elected representatives from provincial and territorial grassroots childcare SMOs.

Since 2000, the CCAAC has been supported by a 'Council of Advocates' to formally bring together allied organizations focused on anti-poverty, immigrant/visible minority women, students, labour, rural childcare, disability and women. Prior to 2007, the CCAAC received some federal project funding to carry out specific research initiatives and was able to maintain up to six paid staff, including an executive director. Since 2007, the CCAAC has operated through the efforts of a paid temporary coordinator, voluntary 
efforts and most recently, a part-time administrative employee funded by supportive labour unions.

On the basis of its grassroots structure and ideological orientation, we expected CCAAC's advocacy tactics to exemplify visible forms of contentious politics such as petitions, protest marches and rallies in public spaces directed at a government which is viewed as an adversary (Taylor and Van Dyke 2004; Snow and Soule 2010). These tactics would have been consistent with CCAAC's long conflictual history with governments.

Prior to 2003, the CCAAC frequently opposed government initiatives that they assessed as negatively affecting ECEC provision. For example, in the 1980s when Mulroney's Conservative government introduced The National Child Care Act, many advocates fought the legislation on the grounds that funding would be available to commercial as well as not-for-profit services, and a child tax credit would be established (White 2001). In the 1990s, childcare advocates opposed the Chrétien Liberal government's abolition of the Canada Assistance Plan (CAP), a mechanism that had subsidized provincial/territorial childcare services, and its replacement, the Canada Health and Social Transfer (CHST), which allowed provinces and territories to spend federal funding transfers (which were less than CAP expenditures) on their own social programme priorities which might not include childcare (Mahon 2009). It was not until 2003 that the federal Human Resources Minister Jane Stewart took, as she described it, "the first step toward a national childcare program" with the multilateral framework agreement on early learning and child care (Friendly and Prentice 2009, p.83).

Over 2003-2005, we anticipated that CCAAC's advocacy strategies would continue to be more conflictual than cooperative, consistent with their past practice. At the same time we expected that the sociopolitical environment of 2003-2005, among other potential conditions, would influence CCAAC's mobilization choices. To investigate these assumptions, we drew on interviews from three groups of ECEC policy stakeholders: CCAAC staff and members; individuals involved in CCCF and childcare research-based organizations who were CCAAC allies; and former federal and provincial-elected government officials and civil servants, who could offer a range of perspectives on this SMO-state relations from 2003 to 2005.

Data for this paper draws on qualitative interviews conducted for a larger project. For this study, we analysed informant responses on questions focused specifically on the relationship between government and the CCAAC from 2003 to 2005. Our analysis of interview data yields several interesting findings that contradict the repertoire of contentious politics strategies we anticipated. CCAAC's advocacy work from 2003 to 2005 is best characterized as conflictual-cooperation, a departure from what is conventionally expected from a grassroots social movement organization.

\section{Theoretical orientation and literature review}

According to Tilly $(2004$, p. 3) a social movement is contentious "in the sense that it involves collective making of claims that, if realized, would conflict with someone else's interests, political in the sense that governments of one sort or another figure in the claim making". Contention is therefore typically evident in campaigns by social actors who try to maximize political opportunities by drawing on repertoires of actions and resources (Staggenborg 2008, p. 5). Broadening this understanding of contentious politics, Giugni 
and Passy (1998) propose the concept of conflictual-cooperation. Through an analysis of two case studies (cross-national solidarity and ecology movements) they found evidence of a repertoire of cooperation with the government built upon an earlier repertoire of contention. This analysis also suggests that the state may work through a top-down process to integrate a social movement and its organizations because the state lacks the knowledge needed for public policy development and problem solving. Giugni and Passy (1998, p. 86) maintain that cooperation between social movement actors and the state is particularly evident during policy implementation because of the "complexity of problems and tasks faced by the government". Three types of cooperation at the individual or collective level and that increase in intensity are identified: consultation (movement actors serve as advisors), integration (actors serve on panels and committees to develop public policies) and delegation (actors assume responsibility for certain tasks in policy implementation). Cooperation is also more likely if the SMO has a formal centralized structure and full-time staff with which the government can regularly work (Giugni and Passy 1998). Drawing on the concept of conflictual-cooperation in their examination of the role of civil society in immigration policy making in Italy, Bozzini and Fella (2008, p. 250) conclude that "the conflictual cooperative relationship between SMOs and institutions defines a qualitatively new form of institutionalization of social actors; SMOs and institutions engage in a process in which they actively search for solutions to common concerns". However, all these scholars agree that conflicts can still arise between SMOs and the state about the means for reaching a common concern.

New social movements driven by post-materialist values and different kinds of social actors (particularly middle-class), are more likely to opt for tactics that involve cooperation with the state (Della Porta and Diani 2006; Giugni and Passy 1998; Staggenborg 2008). The Canadian childcare movement, like the concurrent second-wave women's movement, has long been concerned with quality-of-life issues such as children's wellbeing, work-family balance, along with gender justice although access to childcare is also directly related to the material reality of families' lives. Suh (2011, p. 142) in an examination of the women's movement in Korea and its "dual strategy" of conflict and cooperation to repeal the family headship system showed "that crossing the boundaries between civil society and the state is not only frequent but also sometimes highly efficacious in achieving goals, precisely because the movement in question can capitalize on a much wider than usual array of strategic repertoires by blending participation with mobilization".

Other cross-national studies of women's movements reveal new forms of action that are less publicly visible suggesting that repertoires of contention, structures of mobilization and SMO professionalization processes among other features of social movements can be gendered (Ferree and Mueller 2004, p. 577). Ferree and Mueller (2004, p. 598) claim that "gendered repertories of contention are strategic responses to institutions that structure oppression and opportunity along lines of gender" and that situate men and women in different social locations. Taylor and Van Dyke (2004) also explain that external macrohistorical conditions and internal movement processes (i.e. level of organization among collective actors, cultural frames of meaning to justify collective action and the structural power of the actors) influence tactical repertoires that go beyond visible protesting to cooperation with the state. Giugni and Passy (1998) identify conditions 
of cooperation between a social movement and government which include, at the state level, the inclusive strategies of power holders, the government's political orientation and the openness of public administration to movement actors. Suh $(2011,127)$ puts it another way stating that "the mode of interaction between the social movement and the state is thus far from uniform-conflictive and/or cooperative simultaneously, depending on time, place, and issue".

Some scholars examining childcare campaigns highlight the importance of particular mobilization and organizational resources in influencing political action and policy successes. Tyyska's (1998) focus on Finland, as well as Ball and Charles' (2006) on Wales, found that female political insiders (whether through direct participation or powerful blocs in national politics) created new opportunities for activists to influence childcare policy change. In Sweden and West Germany, Naumann (2005) showed that public childcare mobilization is affected by differences in the political opportunities under which feminists develop their claims and in their collective identity formation as a feminist organization. Kremer (2006) documented how universal childcare provision in Denmark was a result of advocacy by women and social pedagogues from childcare programmes who jointly used a discursive resource-the ideal of professional care- that resonated with the state. Analysing childcare campaigns in six countries, Goss et al. (2007) point to a link between the stratification of the movements' human resources in terms of class, and the childcare "systems" that countries implemented (i.e. a one-class integrated movement resulted in a system of universal provision). In an edited collection, scholars and advocates analysed the Canadian childcare movement before 2001 (Prentice 2001) and recommended a range of repertoires of contention within particular sociopolitical environments (Martin 2001; White 2001). There is little research on how Canadian childcare SMOs mobilized their claims and sought to influence government over the next decade, a turbulent period of social, political and economic highs and lows. Australian scholars, Bown et al. (2009, p. 196), have urged researchers to further examine which factors influence politicians' decisions to undertake policy initiatives, noting that early childhood stakeholders may overestimate who and what influences these decisions and underestimate their own capacities to contribute to decision-making.

Dobrowolsky and Jenson (2004) and Dobrowolsky and Saint-Martin (2009) have called attention to the Canadian state's social investment perspective (investment in the early years yields future economic returns), child poverty and welfare reform strategy in the 1990s. They contend that the social investment perspective has led to the disappearance of women's full citizenship, economic autonomy and well-being through access to childcare from the political agenda. These scholars suggest that grassroots childcare advocacy groups, which are typically confrontational and focused on women's rights, have become marginalized as the social investment perspective ascended. Consistent with this claim, Collier (2012, p. 301) found that while "women" and "gender equality" are not completely absent from policy discussions, feminist messages are more often muted or confused with more state-friendly gender-neutral frames. In contrast, McGrane (2014, p. 1) has recently argued that in Atlantic Canada "an alliance of bureaucratic champions and unified childcare sectors" effectively used a social investment perspective "to take advantage of opportunities presented by new circumstances in their childcare systems to engender structural reforms". Given this variation, it is important to understand how 
and why a conflictual-cooperation CCAAC-government relationship characterizes the period from 2003 to 2005.

\section{Methods}

This study is part of a 4-year research project examining relationships between the Canadian childcare advocacy movement and the professionalization of the early childhood education and care sector in three provinces and on the national level from 2001 to $2010 .^{2}$ Along with content and critical discourse analysis of public advocacy messaging (Langford et al. 2013; Richardson and Langford 2014), 34 semi-structured interviews were conducted with key players in provincial and national childcare SMOs about their advocacy experiences during high and low times of childcare policy action. Interview question topics included: (1) an informant's involvement inside or outside of a childcare SMO; (2) perceptions of a SMO's approach to activism and/or advocacy (political opportunities, organizational goals and strategies, initiatives, internal dynamics, resources such as leadership structure, gender composition, funding, key political and organizational allies, main struggles/barriers to success, future plans); (3) the extent, effects and consequences of professionalization of the ECEC sector on childcare SMOs; (4) and views on Canadian childcare SMOs' successes.

For the purposes of this paper, we focus on three groups, drawn from the larger pool of informants. The first group consisted of nine interviews with key informants involved with the CCAAC between 2003 and 2006 (when a Conservative government was elected). These interviewees included current and former CCAAC board members, executive directors, employees, coordinators and representatives from the Council of Advocates. While they were not asked to self-identify, the majority of CCAAC advocates and CCAAC allies are white, middle-class women between the ages of 35 and 70 . The second group of interviews (a purposive and snowball sample) was made up of five informants considered to be allies of CCAAC, who offered their perspectives on the CCAAC's relationship with the federal government. These interviewees were from other childcare SMOs who advocated for and/or researched childcare policies, the ECEC workforce and professionalization of the sector. The final group consisted of five informants, two male former federal elected leaders, and three women: one senior-level elected provincial official and two federal civil servants who were asked specifically about the government's relationship with childcare advocacy SMOs including CCAAC from 2003 to 2005. In these interviews there was a focus on observations for the future rather than on recollections of the past. Interviews with government policy makers, along with some CCAAC staff members, are consistent with "elite interviews" recommended by Logan et al. (2014, p. 172). Elite interviews involve "high profile personnel who have had access to specialized knowledge and power and provide valuable policy information". They are seen to offer "a means of gaining insight into the multiplicity of influences on policy and to uncover the less easily detectable layers of early childhood (EC) policy development". While it seems counterintuitive to include the leaders of a grassroots childcare advocacy organization in the category of "elite", in the sociopolitical climate over the 2003-2005

${ }^{2}$ Another part of our study specifically included a critical discourse analysis of CCAAC public advocacy messages and identity construction in 2005 and 2008 (author). 
period, CCAAC executives were key players/public figures in policy discussions and development.

In total, this paper draws on the analysis of 18 interviews with informants familiar with CCAAC's relationship with government from 2003 to 2005. In coding and analysis, we focused on responses to the following questions from the longer interviews: What words would you use to describe the Canadian childcare movement? How would you characterize CCAAC's relationship with the federal government before and after 2005? What would they recommend for future childcare advocacy in Canada? Answers to these questions served as a starting point of our analysis. Interview content was organized into charts for analysis and comparison purposes. The chart categorized key quotes that highlighted an informant's perspective on a particular issue or theme (i.e. CCAAC's relationship with the Liberal government from 2003 to 2005). The language used in each quote was then closely analysed and evaluated as being either conflictual, cooperative or both. For example, we analysed informants' recommendations for future advocacy to ascertain whether they would recommend continued cooperation or conflict with the federal government.

We collectively cross-checked for inter-rater reliability, which was close to $95 \%$ agreement with the first two groups of informants because coded content typically were answers to particular interview questions. However, the less-structured interviews with senior-level policy makers (our third group) required us to review the whole transcript and come to agreement about which content was related to the guiding questions. Finally we looked for consistencies and inconsistencies in perspectives about CCAAC's relationship with government from 2003 to 2005.

\section{Results}

Given that the CCAAC is a grassroots SMO, and not a professional organization like the CCCF (the national professional ECEC workforce sector association), we expected to uncover a militant and confrontational characterization of CCAAC activities that would illustrate contentious politics. Instead, we were surprised by what we found.

\section{CCAAC staff and member perspectives}

CCAAC staff and members provided some important and interesting insights about the SMO's relationship with the Liberal government-a relationship which we, after close analysis, identified as conflictual-cooperation. For example, these informants reported that the CCAAC did "push" the government on some issues, but deliberately held back on others. As one senior staff person noted, "we [were] all trying to work towards the greater good even if we [didn't] quite agree [with government] on the details". Another informant echoed this comment and added that the political climate in the early 2000s was both "hopeful and frustrating". When probed about this, she explained it was hopeful because the Liberal government had launched a nascent early childhood development agreement, and "research about child development and the economic benefits of childcare was flourishing". However, from this informant's perspective, it was frustrating that there was still reluctance by the Liberal government to focus specifically on a universal childcare programme as opposed to early "learning", early intervention or family resource programmes which represent more targeted programming. 
While CCAAC advocates experienced a collegial, respectful relationship with the then Minister of Social Development, Ken Dryden, they explained that their conversations were tense at times. A senior staff person described an overall warmth and acceptance between CCAAC advocates and Dryden, but recalled apologizing for pushing him hard on the for-profit childcare issue. She reported Dryden's response: "You have your job to do, I have my job to do, and this is how we get better public policy".

Informants described some tactics that brought the CCAAC into visible conflict with the government. For example, CCAAC released a number of report cards, facts sheets and open letters to educate the public on childcare issues and to call the government to account for their slow action. During the time the federal government and the provinces were negotiating the funding conditions of the bilateral agreements-in-principles, informants described "rolling out" a petition at the first ministers meeting in Newfoundland, holding rallies outside of ministerial meetings and then "going into" the meetings.

At the same time as they adopted some conflictual tactics, CCAAC informants agreed that the period from 2003 to 2005 was a positive, "high time" for the SMO, because it was actively working with government to achieve its goals. Informants characterized this time as one of "optimism" and "opportunity". One informant, who was involved with the CCAAC as both a board member and executive director from 2000 to 2012, referred it to a "great" childcare movement. She characterized the CCAAC as a "glorious wonder of an organization" that had sufficient funding and human resources, and a strong organizational structure and leadership. A pioneering representative on the Council of Advocates drew attention to the societal (and hence government) agreement about the need to invest in new systems such as a national childcare system during the 1990s and into the early 2000s. Another staff person described a "positive momentum with the Martin Liberal government [in which] to some degree he was interested in child poverty issues and that provided us from time to time a door into discussions [with government]".

Several informants noted that during this period (2003-2005), the CCAAC initiated "pivotal pieces of the evidence for the childcare movement". Interestingly, this was partly due to a shift in the way CCAAC acquired funding. Prior to this point, the CCAAC had received Status of Women Canada (SWC) funding for its efforts as a women's rights organization based on feminist principles. An informant observed that being rooted in a women's rights discourse vis-à-vis SWC funding "was good for CCAAC and it was good for child care". In the early 2000s, this funding policy changed to application/projectbased funding. In order to receive funds, the CCAAC was required to produce reports that, according to one informant, had to include what the government "wanted to hear." At the same time, these reports (like From Patchwork to Framework, CCAAC 2004) became part of the evidence used to support the Liberal government initiative to move towards an early learning strategy. Another example came in 2005, when the CCAAC was awarded federal funding (through the Social Development Partnerships Program) for a three-year project titled "Making the Connections", which tracked what provinces were doing with federal social transfers earmarked for childcare. This was considered by some CCAAC informants to be a "significant" advocacy outcome for their organization.

The 2003-2005 period was described as a time when the Liberal federal government and the CCAAC shared expertise, lived experiences and policy analyses to help create the bilateral policy agreements. During this period, informants characterized CCAAC's 
relationship with the federal government as "positive", "exciting and interesting". A former Board member described the sociopolitical climate as shifting considerably. She explained that public discourse about ECEC policy "was a big iceberg" that rose with more information and dialogue, but "now [post 2006] it's sinking in heavy seas and there is just a little tip [of the iceberg] that you can see". Informants described 2003-2005 as a time when the federal Liberal government was supportive of CCAAC's participation in ECEC policy development-"they were working together to produce better childcare policy". From one informant's perspective, the CCAAC was able to influence government's use of language in reference to ECEC (i.e. 'daycare as support for welfare recipients' changed to 'childcare for young children'). Moreover, the CCAAC worked with executive assistants of federal Members of Parliament (MPs) and policy analysts to make sure MPs had sufficient information and/or resources to make their case for a national childcare strategy. The CCAAC had, as one informant stated, "a line of bureaucrats in many provinces and in Ottawa [Canada's capital]" who would talk to staff and MPs about policy initiatives. Indeed, CCAAC advocates could call up ministers and advise them to take particular directions in their approach to a national childcare system. A former staff person added: "You [could] call up...the minister and say...this is what we need you to do-we need you to lead the way and we need you to talk to your colleague in Manitoba".

After 2006, CCAAC's access to and relationship with the federal government abruptly shut down. Indicative of this shift, one former CCAAC staff person recalled being questioned by a Conservative MP about her salary when she appeared before a parliamentary committee in 2007. On another occasion, a Conservative MP met her beside the centennial flame on Parliament Hill and said, "We'll give you money if you support us in our approach". She responded: "It is not about you, it's about children and families and mothers who can't afford to raise their kids. This has been our position forever since we began...and it's not going to change."

CCAAC informants described the political climate after 2006 as "mean-spirited", "chilly" and "frightening". Interview data from this informant group shows no vision of a future in which the CCAAC could again work cooperatively with a national government on ECEC policy. One informant stated the CCAAC has been "deeply affected by the [current] assault on democracy and democratic participation... and the undermining of the legitimacy of critical voices as an essential piece of democracy". The political climate after 2006 sharpened some informants' perspective that the childcare movement is pursuing "a significant new public system in an era of dismantling public systems"a radical demand, and one that rejects the state's neo-liberal/neo-conservative orientation. Two informants, for example, pointed to the movement's claims that "profoundly challenge women's work" and "expose the failure of the free market" to support women's childcare needs. One of these informants also noted that the research evidence that persuaded the Liberal government to launch the childcare bilateral agreements was completely ignored by the Conservative government elected in 2006 which appeared "to be motivated more by ideology than by evidence". Most informants shared the view that the mandate of the CCAAC during a period of conflict with government should be two-fold: to continue to provide analyses of public policy and policy solutions and to engage in public education about childcare issues. 


\section{CCAAC allies}

The second set of interviews were with CCAAC allies, including members of other childcare SMOs, the ECEC workforce and its professional bodies. All five informants in this group regarded CCAAC as a legitimate and "tenacious" representative of the childcare movement at the national level. These informants considered 2003-2005 to be an historic period in which the CCAAC had to make use of the Liberal government's "political will" and their childcare plan as a policy opening and opportunity. However, this set of interview data revealed mixed, and more critical perspectives on CCAAC's strategic approach with government. One informant among this group assessed the CCAAC's use of the government preferred "human capital argument" as being too cooperative and conciliatory. Thus she described the CCAAC's use of this argument as "the wrong thing" although "for the right reason" in that it served as common ground in a SMO-state relationship. Another informant found CCAAC advocates (some she identified as having crossed over from the women's/social justice movements) highly contentious in that they were "always finding fault in any policy proposed by government". After the cancellation of the childcare bilateral agreements, these informants recommended a renewal of the childcare movement with a new generation of advocates and the strengthening of childcare SMO collaboration.

\section{Senior-level elected officials and civil servants}

The third group of informants enriched our findings. The five senior policy makers (two federal elected officials, one provincial-elected official and two civil servants) who were interviewed viewed CCAAC's relationship with the government as generally cooperative. They saw the CCAAC as a legitimate part of a larger sustained childcare movement that had "long struggle[d]" to advance childcare policy at the national level. One government informant acknowledged a "slow recognition (of the importance of the early years) that comes out of all the work of 30 years". Another informant, reminiscing on the strong efforts by the CCAAC, and lamenting the loss of momentum after 2006, remarked that today, "we need a strong movement".

Government insiders reflecting on the 2003-2005 period tended to refer-respectfully-to individual advocates who stood out or with whom they recalled working closely, rather than to the CCAAC as a childcare movement organization. Government leaders who were interviewed recalled having collegial and respectful personal relationships and interactions with CCAAC staff rather than impersonal, bureaucratic and formal meetings. For example, one government informant remarked: "[Our] responsibilities are not different ...You leave your hats at the door... [so that] it is not the government of Canada or the CCAAC...on the table is childcare and making it work. I think for the most part, we were able to do that". Another informant commented that he "got to know the ED [executive director] of CCAAC quite well". Still another informant stated "I did not have any conflict [with advocates] that I'm aware of...I thought we were working quite successfully towards our plan".

Only one informant recalled a time of overt conflict between government and a childcare SMO during the bilateral federal-provincial negotiations, but this conflict about funding for-profit childcare programmes did not involve staff or members of CCAAC. For the most part cooperative and respectful relationships between the government 
and advocates were described-though these relationships did appear to take conscious effort on the part of government representatives. One government informant expressed respect and admiration at the remarkable level of dedication the advocates possessed: "In some cases it is sort of beyond commitment, they have come to embody what it is they are doing. It was not external to them...It's what they do. It's the friends they have. It's the people they like to be around...It was just them". This particular government insider saw this as a strength of advocates, and stated:

They are terrific to deal with because their beliefs are so strong...people who are advocates for childcare-they believe. For the occasional difficult moment that it generates, you get 20 more of the right kind of moments, and you know, I enjoyed it a lot.

The biggest hurdle this informant described when working with CCAAC advocates at this time was the "lingering skepticisms" towards the government on the part of advocates. Given the long history of empty promises and historical childcare policy let-downs, this government leader made an explicit effort to re-establish trust through spending a great deal of time discussing issues, speaking at and attending conferences, and personally meeting with childcare advocates across the country.

When asked what recommendations senior policy makers had for advocates, a number expressed sentiments such as: "keep the faith" and "trust people in the future". In addition, specific tactic/approaches as to how to approach and work effectively with the government were discussed. Recognizing that childcare policy under the Conservative government had been sidelined at the national level, one of these informants recommended staying connected to "childcare movements in other countries where things are happening". In the Canadian political context after 2006, this informant stressed the necessity of forging relationships with the opposition government: "Always consider the opposition as the government in waiting. Find out who can champion this". Indeed these informants communicated a great deal of optimism that "childcare won before, and it can win again". From one policy maker's perspective, the focus going forward should be on the "big fight" - creating a national childcare system—before focusing on "the little fights" (i.e. which childcare services for-profit and/or not-for-profit should be funded).

There was some difference of opinion among this group of informants as to which rationale would be most effective to promote childcare policy when in conversation with government. One key informant adamantly stressed the importance of emphasizing "early learning" (and the economic arguments this discourse is often coupled with) over "childcare". Another informant challenged the need to choose one discourse over the other. He suggested that what is needed instead is a "different understanding," that childcare and early learning are complementary components of lifelong learning. The intergenerational equity rationale, which highlights the lack of economic opportunities young families face today (despite their increased levels of education as compared to a generation before), was also thought to be an important argument to stress with policy makers. Finally, it was interesting to note that these government policy makers in general shied away from childcare framed as a women's issue. One informant overtly cautioned against making it "too much of a feminist issue". Another informant explained the thinking behind such a statement: "if we normalize talking about the need for childcare 
because of all these different reasons and don't say it's a women's issue then it's all of our responsibility...so don't give them the out "saying 'it's a women's issue'...don't give them that...to take it away".

These interviewees stressed the importance of drawing on the language and rationale most congruent with the worldview of the government representative of the time; for example, one informant suggested that "if the minister you're talking to is a scientist, bring scientific empirical data". This recommendation brings attention back to the importance of not only the sociopolitical context in which advocates are operating, but the importance of the immediate personal and relational context of policy negotiations.

These findings about SMO-government relations provide important insights about childcare and childcare policy from the point of view of government officials. Overall, respectful and cordial relations between select government officials who were making policy in the 2003-2005 period and CCAAC advocates who were interviewed in our study were described. Contrary to what we anticipated, our findings suggest that from 2003 to 2005 CCAAC tactics, and government responses point to conflictual-cooperation between a childcare SMO and government. But it is important to emphasize that the CCAAC was only close to government during this 2003-2005 period. Prior to 2003 interactions between CCAAC and the government were largely conflictual and after the election of the Conservatives in 2006 all interactions between CCAAC and the government ceased.

\section{Discussion}

Our analysis of interview data shows that the CCAAC's relationship with the federal government can be characterized as conflictual-cooperation from 2003 to 2005, in that these ECEC stakeholders worked together to produce better policy. Prior to this period, the CCAAC frequently opposed government initiatives that they viewed as negatively affecting ECEC provision. After years of largely conflictual and antagonistic CCAACgovernment relations, our findings suggest that from 2003 to 2005 these relations can be described as conflictual-cooperation. Several factors appear to have encouraged cooperation between the CCAAC and the Liberal government. First, the sociopolitical environment shifted once the social investment perspective emerged as a key rationale for the Martin Liberal government's focus on a national early childhood education and care strategy. As reported by informants, the CCAAC also shifted its advocacy messaging to include this perspective. Secondly, the Liberal government required the complex knowledge held by the CCAAC to launch a national childcare system and was willing to include social movement actors in public policy development (Giugni and Passy 1998). Thirdly, the CCAAC had the internal resources, a formal structure and sufficient staff to undertake a CCAAC/government collaboration.

Our results show that the CCAAC employed a "tactical repertoire" (Taylor and Van Dyke 2004, p. 271) that was responsive to the sociopolitical environment (linked to macrohistorical factors and post-materialist values) and potentially illustrates "apparent shifts in forms of political contention in Western nations". CCAAC's tactics, and its relations with other more professionalized childcare SMOs, also changed depending on the sociopolitical and economic climate. For example, one CCAAC staff person described a point in which distinctions between CCAAC, being outside of government, and CCCF, 
working in or with government, were considerably blurred. The CCAAC benefited from CCCF's insider relationship with the government when the CCCF executive director became a political staffer for the Minister of Social Development. Nevertheless, some CCAAC informants described how at times, national childcare SMOs were in competition with one another, particularly after the Status of Women funding ceased in the early 2000s and they were forced to apply and compete for limited project funding offered by Ottawa. After 2006, when national childcare SMOs struggled to mobilize due to an unfavourable sociopolitical climate and the loss of human and financial resources, the SMOs began to work more closely together.

Prior to 2006, Mahon (2009) describes Liberal policy as "inspired by an increasingly social form of inclusive liberalism" (p. 59). Liberals viewed public investment in childcare as a way to address the social risks of childhood, promote early childhood learning and development and thus invest in a better future for citizens. This social investment perspective was an adjustment to an unrestrained neo-liberal free market approach that disadvantaged the most vulnerable in society but did not return to the old welfare state that had become too costly (Dobrowolsky and Jenson 2004; Dobrowolsky and SaintMartin 2005; Prentice 2009). White (2004 p. 673) argues that during the Liberal federal years the reframing of childcare to early learning as social investment was a "powerful" discursive tool because "it appeals to already existing norms and already institutionalized policy programs (i.e., education as a means of social mobility) and allows governments sympathetic to these arguments to mount a defense of their public investment to both the public and opposition party officials". Fischer's (2003, p. 23) critical, constructivist policy analysis framework also suggests that contemporary political action is "shaped and controlled by the discourses that supply it with meaning" which requires childcare movement actors to be consciously strategic in their own advocacy messaging and tactics and to consider how well this messaging resonates with the state's priorities (Giugni and Passy 1998).

In addition, when the Liberal government began to develop a new childcare strategy in the early 2000s, they were willing to work with civil society actors which included the CCAAC. Thus from 2003 to 2005 in particular, a receptive sociopolitical environment and a window of political opportunity opened up for the CCAAC, an inclusive orientation which Giugni and Passy describe as a critical condition for cooperation. We argue that from 2003 to 2005 the CCAAC adjusted its tactics from contention to conflictual-cooperation in response to a more favourable sociopolitical environment. However this alignment with the Liberal government's approach to state policies reflected highly instrumental and strategic decisions rather than a wholesale endorsement, since we know from other interview analyses that advocates privately prioritize and are motivated in their advocacy work by the conviction that childcare is a women's equity and justice issue (Langford and Richardson 2013). One informant states that the CCAAC chose "the right message [social investment] with the right person [Paul Martin and Ken Dryden] at the right time [inclusive liberalism]". Indeed our interviews with government policy makers show that childcare as a women's equity issue did not resonate with them as a government priority. However, CCAAC staff interviews indicate that the organization reluctantly adopted the "social investment" message and set aside messaging that focused on childcare as a women's equity issue, likely because childcare advocates are 
not completely at odds with a perspective that focuses on child poverty, early learning and intervention. Our earlier studies (Langford et al. 2013; Richardson and Langford 2014) using content and critical discourse analysis also demonstrate that a women's equity discourse was muted in CCAAC public messaging in 2005 and 2008.

While Dobrowolsky and Jenson (2004) maintain that grassroots childcare SMOs are more likely to be confrontational and on the "outside" because of their focus on women's rights, in our view, the CCAAC adjusted its message to focus on social investment and employed conflictual-cooperation strategies. Indeed, it could be argued that CCAAC's flexible and less publicly visible tactical repertoire (i.e. framing the need for childcare as social investment, policy reports and insider negotiations with senior policy makers) contributed to policy success, at least until 2006 when the government changed. Mahon describes the successful policy outcomes: "Between April and November 2005, [the government] negotiated bilateral agreements with all ten provinces. All agreements referred to the QUAD [quality, universal, inclusive, accessible and developmental], though only eight of them made it clear that investments would be made exclusively in regulated child care" (Mahon 2009, p. 59). On the other hand, some informants asked if the CCAAC should have pushed the Liberal government harder earlier: "[we can] take some victory in the bilateral agreements that were signed but clearly they weren't sufficiently embedded [in legislation] as a benefit for families in order to survive an election". Mahon (2009) rightly points out how easy it was for the Conservatives to "kill the policy" on the first day after the election given it had never been legislated (and therefore was not legally binding). Jenson (2009, p. 42) maintains that although the social investment perspective may have served to move childcare policy forward during the Liberal years, it is also "the culprit that set in motion the social mechanism of writing women out" of the childcare story.

Giugni and Passy (1998) claim that SMO/government cooperation arises when the government requires the complex knowledge held by the SMO to develop public policy. All those interviewed recognized that CCAAC's childcare policy expertise had been a key resource for the Liberal government's political social investment goals beginning in the early 2000s and later when the federal-provincial bilateral agreements-in-principle were developed. While the CCAAC did "push" the government at times, informants generally agreed that the CCAAC and the Liberal government [were] "all trying to work towards the greater good". Interestingly senior policy makers did not perceive this "pushing" as conflict perhaps because, as politicians, they regularly dealt with often intense political conflict. Thus, SMO expertise and a common goal set the stage for CCAACgovernment cooperation from 2003 to 2005 . However, the defeat of the Liberal government in 2006 meant that the consultative role the CCAAC played did not evolve into "integration" and/or "delegation" roles which Giugni and Passy (1998) describe as evidence of a deeper cooperative relationship between a SMO and government.

Based on one of Giugni and Passy's conditions for SMO-government cooperationa professionalized SMO-CCAAC's formal structure and the active involvement of its executive director in policy development seems to have contributed to this cooperation. In addition this cooperation could be associated with one of Taylor and Van Dyke's (2004) key features of tactical repertories-an SMO's collective identity. In this case, it may have to do, in part, with the gendered nature of this particular issue and childcare 
advocacy community (Ferree and Mueller 2004). Although not a viewpoint shared by all informants, several indicated that the Canadian childcare movement (of which the CCAAC is a significant part) is more oriented to being cooperative than conflictual. Several advocates, as well as senior policy makers, broadly refer to how the CCAAC "does advocacy" as an organization. A long-time member describes childcare advocacy as an "expression of women's ways", "rooted in the culture of early childhood" in which "relationships matter most" in mobilizing activities. CCAAC's approach to politics is characterized by some informants as "less militant and confrontational than that of the labour movement and feminist organizations" which results in different choices of action. More analysis is needed to assess if CCAAC's repertoire of cooperation is gendered and if it is a "strategic response to institutions that structure oppression and opportunity along lines of gender" (Ferree and Mueller's 2004, p. 598). In addition, this characterization of the CCAAC as more cooperative than conflictual highlights Giugni and Passy's important assertion that the state needs to be willing to work with a SMO in order for a cooperative SMO-government relationship to develop. In other words, prior to 2003, the CCAAC may have had a cooperation orientation consistent with characterizations of new social movements but earlier governments were not open to using this cooperation for policy development. On the basis of our findings, it can be said then that the CCAAC was more likely to be cooperative with government when possible but did not shy away from contention when necessary, although questions remain about the gendered nature of this contention.

Our finding of CCAAC's conflictual-cooperation relationship with the Liberal government from 2003 to 2005 points to, as one informant remarked, "more similarities than differences" between the CCAAC (the grassroots national SMO) and CCCF, (the professional national childcare SMO). Consistent with traditional divisions between grassroots and professionalized SMOs, we expected that informants would report differences, and perhaps even hostility, in how the two SMOs were positioned in relation to government. Informants did identify the mandates of the two SMOs as different, as well as make references to the tactical choices that CCCF had made to play an 'insider' game in contrast to the 'outsider' positioning of the CCAAC. But upon further analysis, the interview data indicate that both national SMOs from 2003 to 2005 had an "insider" relationship with the Liberal government. The more grassroots CCAAC was less confrontational than would have been expected from its past history. Our case study thus contributes to Giugni and Passy's (1998, p. 105) observation that new social movements can involve "a qualitatively new form of incorporation of noninstitutional actors into the political system".

However as Mahon (2009, p. 61) argues "party politics does indeed matter". The day after the 2006 federal election, the conflictual-cooperation relationship CCAAC had with government was severed. After 2006 "the Harper government made it clear that it had no interest in the kind of 'social investment' model favoured by the Liberals" (Mahon, p. 61). Moreover, the Conservative government followed their elimination of the Liberal childcare programme with significant funding cuts to all organizations concerned with children, women and families including the CCAAC and CCCF.

While the CCAAC's cooperation with the Liberal government prior to $2006 \mathrm{might}$ raise questions about whether it is a SMO or a special interest group after 2006 the 
CCAAC was clearly a SMO in conflict with a Conservative government. The unprecedented speed with which the Conservatives rolled back the Liberal's childcare policy sharpened some informants' views that CCAAC demands were radical and represent, as one informant stated, "a major social policy [shift] that would fundamentally change gender relations," a change that [a] Conservative government in particular would "fiercely resist". This roll back illustrates Giugni and Passy's (1998, p. 90) description of an exclusive state with "concentrated...structures of power... [and]...few points of access to external actors" which do not favour a cooperative SMO/government relationship.

Compounding the reality that the CCAAC was in conflict with the Conservative government after 2006, it became extremely difficult for the SMO to mobilize due to the loss of human and financial resources and thus formal and professional structures (Giugni and Passy 1998). We suggest that before 2006 the CCAAC demonstrated a conflictual-cooperation orientation which flourished when the sociopolitical environment was right. After 2006 some informants described the CCAAC as "weak", "fragile" and "down but not completely out". CCAAC's repertoire of contention was limited after 2006 but its tactics suggest a more conflictual stance that returns to its roots. For example, in 2010, the CCAAC launched a campaign, "Child Care is a Right," in which it stressed this return: "the child care movement began as a central issue of the women's right movement so it's natural that we would return to our roots and begin to explore child care from a women's, children and family rights position" (CCAAC website 2013). The CCAAC chose an advocacy message in conflict with the Conservative government's views on child care, one which, according to one senior staff person, would also "excite CCAAC's membership." The new campaign used the international stage to shed light on Canada's lack of progress in relation to childcare provision, which resulted in the Canadian government being taken "to court" in Geneva. But the CCAAC recognized that it could not sustain a major campaign, so instead participated as a partner in the "Code Blue for Child Care" campaign which was funded and led by labour unions. In 2013 a national campaign, "Rethink Child Care", was launched also under union leadership and included CCAAC board members. Despite misgivings about collaboration with labour unions articulated by a few of our informants, the CCAAC did not hesitate to draw on its allies and networks, including labour unions to join more contentious pan-Canadian campaigns. In this regard, CCAAC's advocacy activities run counter to some senior policy makers' perspectives that childcare advocates are typically more cooperative than contentious in their relations with government. On the other hand, as discussed earlier, some CCAAC advocates acknowledge the organization's more cooperative orientation which could be exercised if the government, even a Conservative one, sought cooperation with the SMO. Following one government informant's recommendation, the CCAAC instead worked cooperatively with an opposition party, the New Democratic Party, on Bill C-373 which sought to establish through legislation criteria and conditions in respect of funding for early learning and childcare programmes (did not become law). What seems clear then in CCAAC's mobilization tactics after 2006 is that they were deliberate responses to changes in the sociopolitical climate and in CCAAC's internal resources. Thus while our case study's focus on a particular time period may limit the generalizability of findings, it can illuminate how under certain conditions an SMO and a government established a working relationship to bring about social change. 
After 2006 childcare advocates at the national level did what informants recommended, mentoring a new generation of advocates and building solidarity between childcare SMOs and allies such as unions. Many informants noted that the maintenance of the childcare movement depended on cooperation between the two national SMOs, as neither had funding, or the ear of government. Ironically, one informant suggests contention with the Conservative federal government "helped" bring all the organizations together around a common table. She stated it "helped CCAAC's working relationship with CCCF... [and]...it has helped bring labour into the picture in a way that can't be marginalized". In November 2014, the fourth national childcare conference (organized by childcare SMOs) was held in Winnipeg, Manitoba, the historic site of the previous conferences. Back during the third national conference in 2004, Canada was on the brink of a national childcare system. Over a decade later, the 2014 conference was part of preparations for the anticipated 2015 federal election, in which childcare SMOs, including the CCAAC, made strategic and tactical choices to promote childcare as an election issue. Advocates we interviewed predicted that without a significant shift in the political climate, conflictual-cooperation would not be possible. On October 19, 2015, a majority Liberal government led by Justin Trudeau was elected and committed to developing a new national early learning and child care framework. This presents an opportunity for the CCAAC to re-establish a conflictual-cooperation relationship with Trudeau's Liberal government. Whether or not the CCAAC has the resources and capacity to build this relationship with the government remains to be seen.

\begin{abstract}
Authors' contributions
RL lead investigator. Made substantial contributions to conception and design, acquisition, analysis and interpretation of data; drafted the manuscript and revised it based on feedback and input from co-authors; agreed to be accountable for all aspects of the work in ensuring that questions related to the accuracy or integrity of any part of the work are appropriately investigated and resolved. SP co-investigator. Made substantial contributions to conception and design, acquisition, analysis and interpretation of data; provided substantial feedback on draft manuscript; gave final approval of the version to be published. BR project coordinator. Made substantial contributions to acquisition of data and analysis and interpretation of one portion of the data; provided substantial feedback on manuscript draft; read and approved the final manuscript version. PA co-investigator. Made substantial contributions to conception and design, and acquisition, analysis and interpretation of data; provided feedback on earlier presentations of research results; gave final approval of the version to be published. Each author participated sufficiently in the work to take public responsibility for the content and the analysis and interpretation of research results. In earlier presentations of the research, all authors were identified as members of the research team. All authors read and approved the final manuscript.
\end{abstract}

Author details

${ }^{1}$ School of Early Childhood Studies, Faculty of Community Services, Ryerson University, 350 Victoria Street, Toronto, ON M5B 2K3, Canada. ${ }^{2}$ University of Manitoba, Winnipeg, Canada.

Acknowledgements

We wish to acknowledge funding support from the Social Sciences and Humanities Research Council of Canada for this research project.

\title{
Competing interests
}

None of the authors have financial competing interests. None of the social movement organizations described in the article financially contributed to this manuscript. As part of the research's ethical obligations, all interview informants gave the researchers permission to use interview material for publication purposes. Informants indicated in a consent letter if their name could be used in publications. Three out of the four authors are involved in Canadian provincial childcare movement organizations. Rachel Langford is the president of the Board of Directors of the Association of Early Childhood Educators Ontario. Susan Prentice serves as a member of the Childcare Coalition of Manitoba and Brooke Richardson is a member of the Ontario Advocates for Progressive Childcare Policy.

Received: 24 March 2015 Accepted: 4 January 2016

Published online: 15 January 2016 


\section{References}

Albanese, P. (2009). \$7/day, \$7/hour, 7 days a week: juggling commutes, shift work and childcare in a changing ("new") economy. In J. Klaehn (Ed.), Road blocks to equality (pp. 26-40). Toronto: Black Rose Books.

Bailey, S. (2008). "Regulated child-care spaces way down, report says." Globe and Mail, April 11, 4.

Ball, W., \& Charles, N. (2006). Feminist social movements and policy change: Devolution, children and domestic violence policies in Wales. Women's Studies International Forum, 29, 172-183.

Bown, K., Sumsion, J., \& Press, F. (2009). Influences on politicians' decision making for early childhood education and care policy: What do we know? What don't we know? Contemporary Issues in Early Childhood, 10(3), 194-217.

Bozzini, E., \& Fella, S. (2008). The role of civil society in immigration policy making in Italy: Changing patterns of conflictual cooperation. Policy and Politics, 36(2), 245-259.

Briskin, L., \& Eliasson, M. (1993). Women's organizing and public policy. Montreal and Kingston: McGill-Queen's University Press.

CCAAC. (2004). From patchwork to framework: A child care strategy for Canada. Ottawa: Author.

CCAAC. (December 5, 2005). Conservatives taxable allowance won't deliver quality childcare. Retrieved 19 May 2015 from https://ccaacacpsge.files.wordpress.com/2014/10/contax.pdf.

Collier, C. (2012). Feminist and gender-neutral frames in contemporary child-care and anti-violence policy in Canada. Politics and Gender, 8, 283-303.

Della Porta, D., \& Diani, M. (2006). Social movements: An introduction. Malden: Blackwell Publishing.

Dobrowolsky, A. (2009). Women and public policy in Canada: Neo-liberalism and after?. Toronto: Oxford University Press.

Dobrowolsky, A., \& Jenson, J. (2004). Shifting representations of citizenship: Canadian politics of "women" and "children". International Studies in Gender, State and Society, 11(2), 154-180.

Dobrowolsky, A., \& Saint Martin, D. (2005). Agency, actors and change in a child focused future: Path dependency problematised. Commonwealth and Comparative Politics, 43(1), 1-33.

Ferree, M., \& Mueller, C. (2004). Feminism and the women's movement: A global perspective. In D. Snow, S. Soule, \& H Kriesi (Eds.), The Blackwell companion to social movements (pp. 576-607). Malden: Blackwell Publishing.

Fischer, F. (2003). Reframing public policy: Discursive politics and deliberative practices. Oxford: Oxford University Press.

Friendly, M., \& Prentice, S. (2009). About canada: Child care. Halifax: Fernwood Publishing.

Giugni, M. G., \& Passy, F. (1998). Contentious politics in complex societies: New social movements between conflict and cooperation. In M. G. Giugni, D. McAdam, \& C. Tilly (Eds.), From contention to democracy. Lanham: Rowman and Littlefield.

Goss, K., Shames, S., \& Wagner, D. (2007, April). Stratification, mobilization, and policy design: The case of childcare in six nations. Paper presented at the annual meeting of the Midwest Political Science Association, Chicago.

Jenson, J. (2009). Writing gender out: the continuing effects of the social investment perspective. In A. Dobrowolsky (Ed.) Women and public policy in Canada (pp. 25-47). Toronto: Oxford University Press.

Kremer, M. (2006). The politics of ideals of care: Danish and Flemish childcare policy compared. Social Policy: International Studies in Gender, State and Society, 13(2), 261-285.

Langford, R., Richardson, B. (2013). Where is gender in child care advocacy? Exploring the Canadian child care movement through a gender analysis in an age of neoliberalism. International Conference on Public Policy, Grenoble, France

Langford, R., Prentice, S., Albanese, P., Summers, B., Messina-Goertzen, B. \& Richardson, B (2013) Professionalization as an advocacy strategy: a content analysis of Canadian child care social movement organizations' 2008 discursive resources. Early Years: An International Research Journal, 33(3), 302-317. doi:10.1080/09575146.2013.789489.

Logan, H., Sumsion, J., \& Press, F. (2014). Uncovering hidden dimensions of Australian early childhood policy history: Insights from interviews with policy 'elites'. European Early Childhood Education Research Journal, 22(5), 711-722. doi:1 $0.1080 / 1350293 \times .2014 .969086$.

Mahon, R. (2009). Childcare and varieties of liberalism in Canada. In A. Dobrowolsky (Ed.), Women and public policy in Canada (pp. 48-64). Toronto: Oxford University Press.

Martin, J. (2001). History, lessons and a case for change in childcare advocacy. In S. Prentice (Ed.), Changing child care: Five decades of childcare advocacy and policy in Canada (pp. 171-185). Halifax: Fernwood Publishing.

McGrane, D. (2014). Bureaucratic champions and unified childcare sectors: neo-liberalism and inclusive liberalism in Atlantic Canadian childcare systems. International Journal of Child Care and Education Policy, 8 (1) http://www.ijccep. com/content/8/1/1

Naumann, I. (2005). Childcare and feminism in West Germany and Sweden in the 1960s and 1970s. Journal of European Social Policy, 15(1), 47-63.

Prentice, S. (Ed.). (2001). Changing child care: five decades of childcare advocacy and policy in Canada. Halifax: Fernwood Publishing.

Prentice, S. (2009). High stakes: The "invisible" child and the economic reframing of child care. Signs: Journal of Women in Culture and Society. 34(3), 687-710.

Richardson, B., \& Langford, R. (2014). A shifting collective identity: a critical discourse analysis of the Child Care Advoacy Association of Canada's public messaging in 2005 and 2008. Critical Discourse Studies. doi:10.1080/17405904.2014.9 62068.

Snow, D., \& Soule, S. (2010). A primer on social movements. New York: W.W. Norton \& Company.

Staggenborg, S. (2008). Social movements. New York: Oxford University Press.

Suh, D. (2011). The dual strategy and gender policies of the women's movement in Korea: family headship system repeal through strategic innovation. Sociological Focus, 44(2), 124-147.

Taylor, V., \&Van Dyke, N. (2004). Tactical repertoires of social movements. In D. Snow, S. Soule, \& H. Kriesi (Eds.), The Blackwell companion to social movements (pp. 262-293). Malden: Blackwell Publishing.

Tilly, C. (2004). Social movements, 1768-2004. Boulder: Paradigm Publishers.

Tyyska, V. (1998). Insiders and outsiders: Women's movements and organizational effectiveness. The Canadian Review of Sociology and Anthropology, 35(3), 391-410. 
White, L. (2001). From ideal to pragmatic politics: National childcare advocacy groups in the 1980s and 1990s in Prentice, S. (Ed). (2001). Changing Child Care: Five Decades of Childcare Advocacy and Policy in Canada (pp. 97-115). Halifax: Fernwood Publishing.

White, L. (2004). Trends in Child Care/Early Childhood Education/Early Childhood Development Policy in Canada and the United States. The American Review of Canadian Studies (Winter): 665-687.

Submit your manuscript to a SpringerOpen ${ }^{\circ}$ journal and benefit from:

Convenient online submission

Rigorous peer review

- Immediate publication on acceptance

- Open access: articles freely available online

- High visibility within the field

- Retaining the copyright to your article

Submit your next manuscript at $\mathbf{s p r i n g e r o p e n . c o m ~}$ 